\title{
Genetic instability of sugarcane plants derived from meristem cultures
}

\author{
Maria Imaculada Zucchi ${ }^{1}$, Hideto Arizono ${ }^{2}$, Vicente Alberto Morais ${ }^{3}$, Maria Helena Pelegrinelli Fungaro ${ }^{4}$ \\ and Maria Lúcia Carneiro Vieira ${ }^{1}$ \\ ${ }^{1}$ Departamento de Genética, Escola Superior de Agricultura "Luiz de Queiroz”, Universidade de São Paulo, \\ Piracicaba, SP, Brazil. \\ ${ }^{2}$ Departamento de Biotecnologia Vegetal, Centro de Ciências Agrárias, Universidade Federal de São \\ Carlos, Araras, SP, Brazil. \\ ${ }^{3}$ Seção de Fitopatologia, Centro de Tecnologia Copersucar, Piracicaba, SP, Brazil. \\ ${ }^{4}$ Departamento de Biologia Geral, Universidade Estadual de Londrina, Londrina, PR, Brazil.
}

\begin{abstract}
The RADP (Random amplified polymorphic DNA) technique was used to detect tissue-culture-induced variations in sugarcane. Plants of the Brazilian variety RB83-5486 propagated via rhizomes and via meristem cultures were studied. The polymorphism rate for 98 RAPD loci was $6.93 \%$ when the plants derived from meristems. Besides, in order to evaluate the influence of the number of subcultures on the generation of somaclonal variation, field-grown RB83-5486 plants derived from 10 meristems were studied after five subcultivations. Although different rates of polymorphism were observed, there was no direct association with the stage of subcultivation. The analysis of plants of two sugarcane varieties cultivated in vitro from meristems showed that variety RB83-5486 was more unstable than variety SP80-185.
\end{abstract}

Key words: sugarcane, somaclonal variation, meristem cultures, phenotypic instability, RAPD.

Received: March 5, 2002; accepted: March 25, 2002.

\section{Introduction}

Sugarcane (Saccharum sp.) is globally the main source of raw material for the production of sugar, followed by sugar beets (Beta vulgaris). Although many countries are sugarcane producers, only six of them account for $65 \%$ of the world's entire sugarcane production, Brazil being the largest one. Data from the Food and Agriculture Organization (http://apps.fao.org) show that in 1998 the world area devoted to sugarcane cultivation was $19,438,105$ hectares, with Brazil accounting for about one fourth of this area.

Currently, a proportion part of the sugarcane plantlets are produced by tissue culture methods. The terminal portions of the stalks are collected from disease-free field plants. Shoot tips $(4 \mathrm{~cm})$ are then obtained by removing older surrounding leaves. After disinfection, the apical meristems are aseptically excised and placed on liquid MS medium (Murashige and Skoog, 1962) for up to 30 days. Culturing is done by transferring the plantlets to the same medium containing benzyl-aminopurine to produce shoot branches, followed by subculturing for up to six months

Send correspondence to Maria Lúcia Carneiro Vieira. Departamento de Genética, ESALQ-USP, Piracicaba, SP, Brazil. E-mail: mlcvieir@carpa.ciagri.usp.br.
(Lee, 1987). At a multiplication rate of about five plantlets per flask and one subculturing per month, it is feasible to obtain as many as 20,000 plantlets from a single meristem.

Sugarcane micropropagation from apical meristems is very useful in sugarcane breeding programs, because of the time it saves in multiplying the promising varieties and clones and in facilitating the acquisition of large volumes of material. Meristem culturing can also be useful in eliminating pathogens (Hendre et al., 1983).

Despite the advantages of in vitro propagation, phenotypic instability has been observed in micropropagated species, including sugarcane (Irvine et al., 1984; Bailey and Bechet, 1989; Irvine, 1991; Peros et al., 1994; Burner and Grisham, 1995; Taylor et al., 1995). Larkin and Scowcroft (1981) coined the term somaclonal variation to describe the occurrence of genetic variants derived from in vitro procedures. Factors such as explant source, time of culture, number of subcultures, phytohormones, genotype, media composition, the level of ploidy and genetic mosaicism are capable of inducing in vitro variability (Silvarolla, 1992).

The stimulation of axillary bud development is not expected to generate genetic instability, since this technique uses the normal ontogenetic route for branch growth by lateral meristems. In comparison, plant regeneration 
produced by culturing tissue sections lacking a preformed meristem (adventitious origin) (reviewed by Phillips et al., 1990; Phillips et al., 1994; Karp, 1995) or derived from callus and cell cultures (de novo origin) (Damasco et al., 1996) is more susceptible to somaclonal variation. In the case of sugarcane, shoot tip culturing induces considerable phenotypic variability (Burner and Grisham, 1995).

Molecular markers are widely used to detect and characterize somaclonal variation at the DNA level (Ford-Lloyd et al., 1992; Cloutier and Landry, 1994; Barrett et al., 1997). Of the available techniques, RAPD is among the most useful ones (Rani et al., 1995; Taylor et al., 1995; Shoyama et al., 1997; Todoroviska et al., 1997; Rout et al., 1998). Changes in the RAPD pattern may result from the loss/gain of a primer annealing, caused by point mutations or by the insertion or deletion of sequences or transposition elements (Peschke et al., 1991).

In this study, we used RAPD to investigate the somaclonal variation in Brazilian sugarcane varieties derived from meristem cultures. Clones not derived from in vitro procedures were simultaneously analyzed.

\section{Material and Methods}

\section{Plant material}

Two Brazilian varieties of sugarcane were used: RB83-5486, in which in vitro propagation causes phenotypic instability, and SP80-185, which performs well when micropropagated, having the same appearance as the original clone.

The high rate of phenotypic instability in RB83-5486, when micropropagated, impairs its commercial production. The original clone underwent meristem culture in 1993 and was in the second vegetative propagation at the time of this study. Initially, four aberrant plants collected at the Barra Grande Sugar Mill, State of São Paulo, were used. Plants were selected based on their aberrant phenotype and designated $\mathrm{M}_{1}, \mathrm{M}_{2}, \mathrm{M}_{3}$ and $\mathrm{M}_{4}$. These somaclonal plants had a very thin top and excessive lateral bud formation; $\mathrm{M}_{2}$ also had an excessive number of calluses between knots.
To determine the occurrence of intraclonal variation, 48 plants of the original clone were collected and compared to 48 normal plants of the same variety propagated via rhizomes.

In order to evaluate the influence of the number of subcultures on the generation of somaclonal variants, apical meristems were excised from 10 field plants of the original RB83-5486 clone and subcultured five times. After each subculture, part of the meristem-derived plantlets were acclimatized to greenhouse conditions. Later, the experimental material was planted in fields around the Ester Sugar Mill (State of São Paulo). The DNA of 50 plants was then extracted (Figure 1).

Thirty plantlets of each variety (RB83-5486 and SP80-185) derived from the in vitro propagation of five meristems were also analyzed. Each meristem and its derivatives were studied during six subcultures. This experiment was conducted at the Copersucar Technology Center (CTC).

\section{Extraction and quantification of genomic DNA}

DNA was extracted using the CTAB method, described by Murray and Thompson (1980) and Rogers and Bendich (1985), with modifications. Approximately $250 \mathrm{mg}$ of fresh tissue from each individual plant were powdered in liquid nitrogen.

DNA was quantified by electrophoresis $(3 \mathrm{~V} / \mathrm{cm})$ in $0.8 \%$ agarose gels $(\mathrm{w} / \mathrm{v})$ by comparison to known concentrations (20-400 ng) of lambda phage DNA. The DNA was visualized by ethidium bromide staining, and the original DNA solutions were then diluted to $5 \mathrm{ng} / \mathrm{L}$ for PCR reactions.

\section{Amplification conditions}

PCR amplifications were performed in a Perkin-Elmer-Cetus thermocycler, as described by Vieira et al. (1997), with modifications. The reaction mixture contained $10 \mathrm{mM}$ Tris- $\mathrm{HCl}, \mathrm{pH} 8.3,50 \mathrm{mM} \mathrm{KCl}, 2.0 \mathrm{mM} \mathrm{MgCl}_{2}$, $0.2 \mathrm{mM}$ dNTPs, $0.25 \mu \mathrm{M}$ primer (Operon Technologies), 20 or $40 \mathrm{ng}$ of template DNA, 2 units of Taq polymerase, and ultra-pure autoclaved water in a final volume of $25 \mu \mathrm{L}$. The reactions were subjected to 40 amplification cycles, after an initial denaturation at $92{ }^{\circ} \mathrm{C}$ for $4 \mathrm{~min}$. Each cycle

\begin{tabular}{|c|c|c|c|c|c|c|c|}
\hline \multirow[b]{2}{*}{ Subculture } & \multicolumn{3}{|c|}{$\mathrm{Me}_{1}$} & $\ldots$ & \multicolumn{3}{|c|}{$\mathrm{Me}_{10}$} \\
\hline & In vitro & Field transference & DNA extraction & & In vitro & Field transference & DNA extraction \\
\hline $1^{\mathrm{st}}$ & $\downarrow$ & $\rightarrow$ & Y & $\ldots$ & $\downarrow$ & $\rightarrow$ & $\mathrm{Y}$ \\
\hline $2^{\text {nd }}$ & $\downarrow$ & $\rightarrow$ & $\mathrm{Y}$ & $\ldots$ & $\downarrow$ & $\rightarrow$ & $\mathrm{Y}$ \\
\hline $3^{\text {rd }}$ & $\downarrow$ & $\rightarrow$ & $\mathrm{Y}$ & $\ldots$ & $\downarrow$ & $\rightarrow$ & Y \\
\hline $4^{\text {th }}$ & $\downarrow$ & $\rightarrow$ & $\mathrm{Y}$ & $\ldots$ & $\downarrow$ & $\rightarrow$ & $\mathrm{Y}$ \\
\hline $5^{\text {th }}$ & $\downarrow$ & $\rightarrow$ & $\mathrm{Y}$ & $\ldots$ & $\downarrow$ & $\rightarrow$ & $\mathrm{Y}$ \\
\hline
\end{tabular}

Figure 1 - Experimental protocol for evaluating the influence of the number of subcultures on the production of somaclonal variation. As a single meristem produces 5 to 6 shoots by cytokinin stimulation, part of them were acclimatized and transferred to the field. After each generation, the DNA of ten field plants derived from the apical meristems $\left(\mathrm{Me}_{1}, \mathrm{Me}_{2} \ldots \mathrm{Me}_{10}\right)$ was extracted for molecular analysis. 
consisted of $45 \mathrm{~s}$ at $92{ }^{\circ} \mathrm{C}, 1.5 \mathrm{~min}$ at $40{ }^{\circ} \mathrm{C}$, and $1.5 \mathrm{~min}$ at $72{ }^{\circ} \mathrm{C}$, with a final $5 \mathrm{~min}$ extension at $72^{\circ} \mathrm{C}$.

The amplification products were run on $1.4 \%$ agarose gels at $3 \mathrm{~V} / \mathrm{cm}$. A DNA ladder (100 bp, Pharmacia) was used as molecular weight marker. The gels were photographed under UV light, using a Gel-Doc 2000 photo documentation system (Bio-Rad).

\section{Primer selection}

After optimization of the amplification conditions, useful primers were selected from 20 oligomers in kit A (OPA-01 to OPA-20), two in kit F (OPF-03 and OPF-04) and three primers in kit E (OPE-01, OPE-05 and OPE-06).

\section{Data analysis}

The data were analyzed using locus-to-locus gel readings, and the rates of in vitro DNA polymorphism were calculated and given as percentage of the total number of bands for the sugarcane clones.

\section{Results and Discussion}

\section{Aberrant phenotypes}

Nine oligonucleotides (OPA-01, OPA-02, OPA-03, OPA-04, OPA-07, OPA-08, OPA-09, OPA-10, OPA-16) were selected based on the repeatability of their amplification profiles. Fragments ranged in size from $200 \mathrm{bp}$ to $3 \mathrm{~kb}$.

The original clone pattern was very similar to the aberrant plants $\left(\mathrm{M}_{1}, \mathrm{M}_{2}, \mathrm{M}_{3}\right.$ and $\left.\mathrm{M}_{4}\right)$. Only four out of 98 loci were found to be polymorphic in the aberrant plants, as detected by primers OPA-02 (one locus), OPA-04 (two loci) and OPA-08 (one locus), corresponding to a $4.08 \%$ rate of polymorphism (Table 1). Gels that showed RAPD polymorphisms were run at least two more times.

\section{Intraclonal variation}

Of the 98 loci analyzed using DNA from 48 rhizome-derived RB83-5486 plants, only one was polymor-

Table I - DNA polymorphisms detected in the aberrant plants $\left(\mathrm{M}_{1}, \mathrm{M}_{2}, \mathrm{M}_{3}\right.$ and $\mathrm{M}_{4}$ ) in comparison to the original clone profile.

\begin{tabular}{|c|c|c|c|}
\hline $\begin{array}{l}\text { Primer } \\
\text { designation }\end{array}$ & Sequence & $\begin{array}{c}\text { Loci } \\
\text { generated }\end{array}$ & $\begin{array}{l}\text { Polymorphic } \\
\text { fragments (bp) }\end{array}$ \\
\hline OPA-01 & ${ }^{5} \mathrm{CAGGCCCTTC}^{3^{\prime}}$ & 9 & \\
\hline OPA- 02 & 5'TGCCGAGCTG ${ }^{3}$ ' & 10 & 500 \\
\hline OPA-03 & 5'AGTCAGCCAC ${ }^{3}$ ' & 11 & - \\
\hline OPA-04 & 5'AATCGGGCTG ${ }^{3}$ & 14 & $900 ; 450$ \\
\hline OPA-07 & 5'GAAACGGGTG' & 10 & - \\
\hline OPA- 08 & 5'GTGACGTAGG ${ }^{3{ }^{\prime}}$ & 15 & 600 \\
\hline OPA-09 & ${ }^{5}$ GGGTAACGCC ${ }^{3}$ & 8 & - \\
\hline OPA-10 & '5'GTGATCGCAG ${ }^{3}$ & 9 & - \\
\hline OPA-16 & ${ }^{5} \mathrm{AGCCAGCGAA}^{3}$ & 12 & - \\
\hline
\end{tabular}

phic, indicating an intrinsic polymorphism rate of $1.02 \%$. A new $900 \mathrm{bp}$ amplification product was found in a single plant. It was detected by primer OPA-04. Such a variation may derive from point mutations or alterations in chromosome number. The effects of pre-existing DNA polymorphism in clonally propagated plants were also taken into consideration. Plant meristems have an organized layer structure, in dicots usually three, in monocots even more. Cells in the tunica divide predominantly anticlinally, and thus do only rarely change position within the differentiated meristem. Therefore, the meristem of vegetatively propagated plants can represent a complex chimerical structure.

Low levels of morphological variation have been found previously in RB83-5486 plants propagated through rhizomes (Zucchi et al., 1996), indicating that this clone per se shows a variation that tends to be increased by in vitro propagation. This variation includes stalks with a smaller diameter and shortened internodes. Various plants presented the same abnormal phenotype. A possible chimeric nature of the cultivar used may also be the reason for its high phenotypic instability, rather than an intrinsic genetic factor.

In the 48 plants propagated by meristem culture, the corresponding rate of polymorphism was $6.93 \%$ (Table 2 ). Tissue culture was thus responsible for the generation of new variability, since a 7(.0)-fold increase in the rate of molecular polymorphism was observed. Heinz and Mee (1971), working with callus-derived cultures from sugarcane variety H50-7209, detected clones with chromosomal numbers ranging from $2 \mathrm{n}=94$ to 120 . In contrast, chromosome stability was described for varieties NA56-79 $(2 \mathrm{n}=114)$ and $\operatorname{Co} 419(2 \mathrm{n}=213)$ by Silvarolla and Aguiar-Perecin (1994), who developed a technique to obtain intact somatic metaphase sugarcane cells. Together, these observations suggest either that some genotypes are more susceptible to somaclonal variation, or that the in $v i$ tro instability is actually a consequence of a genotype versus culture medium interaction.

Table II - DNA polymorphisms detected in 48 RB83-5486 field plants derived from meristem cultures.

\begin{tabular}{|c|c|c|c|}
\hline $\begin{array}{l}\text { Primer } \\
\text { designation }\end{array}$ & Sequence & $\begin{array}{c}\text { Loci } \\
\text { generated }\end{array}$ & $\begin{array}{l}\text { Polymorphic } \\
\text { fragments (bp) }\end{array}$ \\
\hline OPA-02 & ${ }^{5}{ }^{\text {TGCCGAGCTG }}{ }^{3}$ & 10 & 500 \\
\hline OPA-03 & 5'AGTCAGCCAC ${ }^{3}$ ' & 11 & - \\
\hline OPA-04 & ${ }^{5} \mathrm{AATCGGGCTG}^{3}$ ' & 14 & $900 ; 450$ \\
\hline OPA-07 & ${ }^{5}$ 'GAAACGGGTG ${ }^{3}$ & 10 & - \\
\hline OPA-08 & $5^{\prime}$ GTGACGTAGG ${ }^{3}$ ' & 15 & $600 ; 400$ \\
\hline OPA-10 & ${ }^{5}$ GTGATCGCAG ${ }^{3}$ & 9 & - \\
\hline OPA-16 & $5^{\prime} \mathrm{AGCCAGCGAA}^{3}$ & 12 & - \\
\hline OPA-18 & 5'AGGTGACCGT ${ }^{3}$ ' & 12 & $750 ; 450$ \\
\hline OPA-20 & 5'GTTGCGATCC ${ }^{3}$ & 8 & - \\
\hline
\end{tabular}




\section{The influence of subculturing}

Thirty-two polymorphic loci were detected in the RAPD loci analyzed after five subcultures. Polymorphism was calculated based on the percentage of polymorphic loci (32) out of all loci ( $98 \times 10$ meristem-derived plants), which corresponded to a mean rate of $3.26 \%$ (Figure 2, top). The polymorphism rate of each of the meristem-derived groups was: $0.0 \%\left(\mathrm{Me}_{1}\right), 5.10 \%\left(\mathrm{Me}_{2}\right), 2.04 \%\left(\mathrm{Me}_{3}\right), 3.06 \%\left(\mathrm{Me}_{4}\right)$, $3.06 \%\left(\mathrm{Me}_{5}\right), 5.10 \%\left(\mathrm{Me}_{6}\right), 3.06 \%\left(\mathrm{Me}_{7}\right), 4.08 \%\left(\mathrm{Me}_{8}\right)$, $3.06 \%\left(\mathrm{Me}_{9}\right)$, and $4.08 \%\left(\mathrm{Me}_{10}\right)$. These polymorphisms occurred in all subcultivations, and did not increase with the
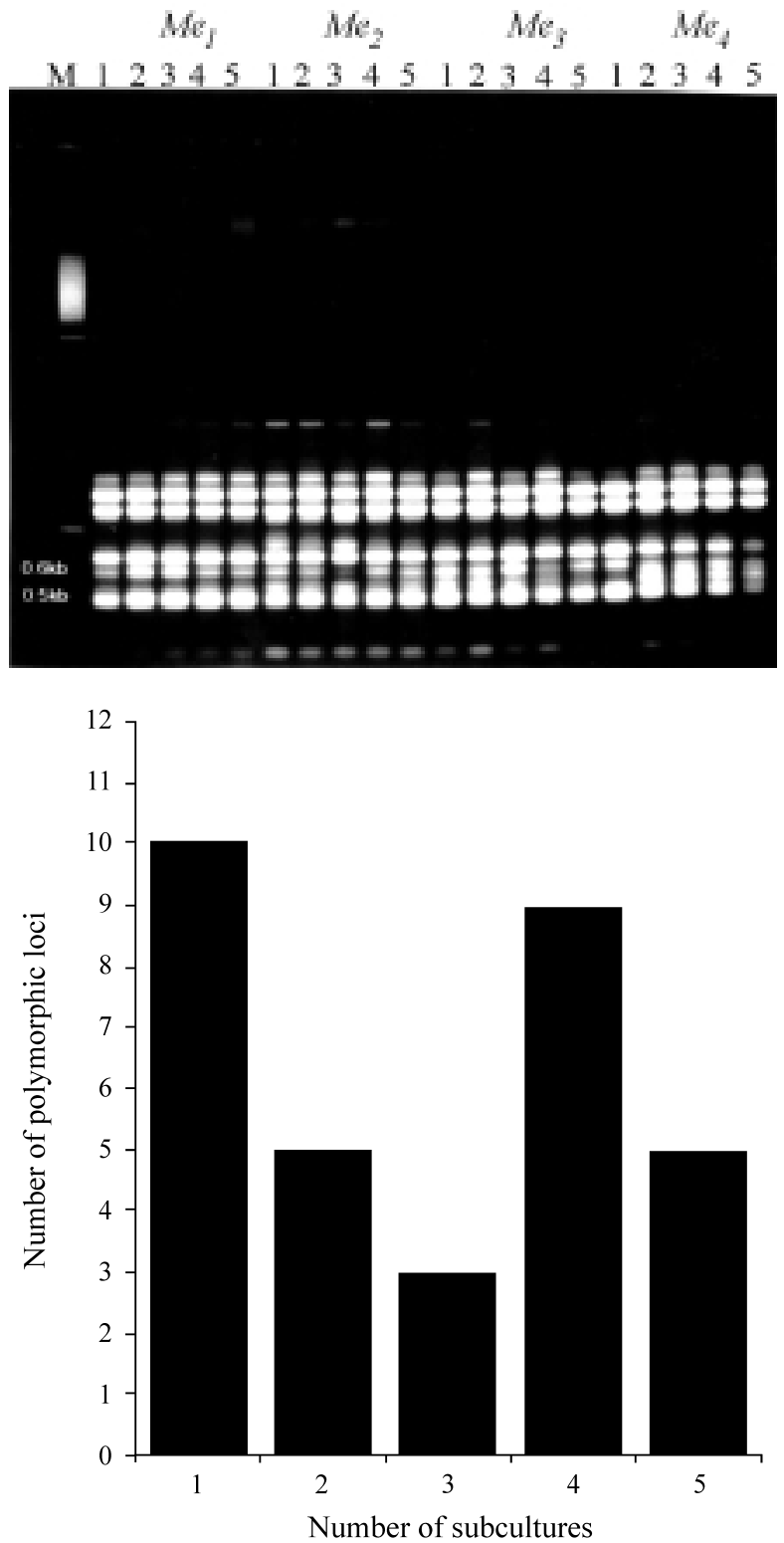

Figure 2 - RAPD profile of 20 RB83-5486 plants obtained by meristem cultures $\left(\mathrm{Me}_{1}, \mathrm{Me}_{2}, \mathrm{Me}_{3}\right.$ and $\left.\mathrm{Me}_{4}\right)$ in five stages of subcultivation (1-5) (for the PCR reactions, primer OPA-02 was used); molecular weight marker (M, $100 \mathrm{bp}$ ladder, Pharmacia (left of the figure top); influence of the number of subcultures on the molecular variation detected by RAPD in sugarcane plants (bottom). number of subcultures. A large number of variant loci were observed from the beginning of the process, indicating that culturing meristems in vitro is stressful to the plant genome (Figure 2, bottom). An explanation for this finding is that the pattern observed is in accordance with the segregation of genotypes from a chimeric meristem, resulting in high polymorphisms in the initial generation, due to the breakdown of the meristematic organization, forming a heterogeneous population of homogeneous plants, but, over consecutive generations, lower polymorphisms, due to a stochastic process.

On the other hand, in vitro stress may cause the genome to respond by DNA methylation, and this may modify the RAPD profile through the insertion or excision of transposons (Hirochika et al., 1996). Kovarik et al. (1997) suggested that epigenetic changes in the level of methylated DNA might play an important role in the mechanism of adaptation to environmental stress.

The RAPD technique reveals DNA polymorphisms as differences in the amplification patterns, and uses primers of random sequences that search for complementarity in the genome. It is suggested that RAPD bands possibly represent mainly repetitive DNA (Grattapaglia and Sederoff, 1994). Polymorphism in repetitive DNA sequences has frequently been observed during plant propagation by tissue culture (Smulders et al., 1995) and undergoes more alterations than the coding sequences. In vitro stress may provoke changes at preferential sites, such as repetitive DNA, thereby activating transposable elements.

\section{Analysis of in vitro cultured plantlets}

The number of polymorphic loci in RB83-5486 plantlets was $16(15.84 \%)$. In the SP80-185 variety, six loci $(6.06 \%)$ were found to be variable (Table 3$)$. In vitro stress was seen in all phases (six subcultivation stages) of sugarcane micropropagation in both varieties. However, based on the RAPD profiles, variety RB83-5486 was more unstable than SP80-185. Thus, certain genotypes such as the RB83-5486 variety require more appropriate conditions for culturing.

In conclusion, intrinsic molecular variability exists among sugarcane clones. Meristem culturing increases the rate of polymorphism, which is also influenced by the sugarcane genotype. This in vitro stress occurs at all stages of micropropagation.

\section{Acknowledgments}

This work was funded by grants from Fundação de Amparo à Pesquisa do Estado de São Paulo (FAPESP, 97/4617-8) and from Conselho Nacional de Desenvolvimento Científico e Tecnológico (CNPq). The authors thank C. A. de Oliveira for excellent technical assistance. Universidade Federal de São Carlos kindly provided the plant material. 


\section{References}

Bailey RA and Bechet GR (1989) A comparison of seedcane derived from tissue culture with conventional seedcane. Proc. S. Afr. Tech. Assoc. 63:125-129.

Barrett C, Lefort F and Douglas GC (1997) Genetic characterization of oak seedlings, epicormic, crown and micropropagated shoots from mature trees by RAPD and microsatellite PCR. Sci. Hortic. 70:319-330.

Burner DM and Grisham MP (1995) Induction and stability of phenotypic variation in sugarcane as affected by propagation procedure. Crop Sci. 35:875-880.

Cloutier S and Landry BS (1994) Molecular markers applied to plant tissue culture. In Vitro Cell. Develop. Biol. 30:32-39.

Damasco OP, Graham GC, Henry RJ, Adkins SW, Smith MK and Godwin ID (1996) Random amplified polymorphic DNA (RAPD) detection of dwarf off-types in micropropagated Cavendish (Musa spp. AAA) bananas. Plant Cell Rep. 16:118-123.

Ford-Lloyd BV, Sabir A, Newbury HJ, Todd C and Catty J (1992) Determination of genetic stability using isozymes and RFLPs in beet plants regenerated in vitro. Theor. Appl. Genet. 84:113-117.

Grattapaglia D and Sederoff R (1994) Genetic linkage maps of Eucalyptus grandis and Eucalyptus urophylla using a pseudo-testcross: mapping strategy and RAPD markers. Genetics 137:1121-1137.

Heinz DJ and Mee WP (1971) Morphological, cytogenetic, and enzymatic variation in Saccharum species hybrid clones derived from callus tissue. Am. J. Bot. 58:257-262.

Hendre RR, Iyer RS, Kotwal M, Khuspe SS and Mascarenhas AF (1983) Rapid multiplication of sugarcane by tissue culture. Sugar Cane 1:5-8.

Hirochika H, Sugimoto K, Otsuki Y, Tsugawa H and Kanda M (1996) Retrotransposon of rice involved in mutations induced by tissue culture. Proc. Natl. Acad. Sci. USA 97:7783-7788.

Irvine JE (1991) The frequency of marker changes in sugarcane plants regenerated from callus culture, II. Evidence for vegetative and genetic transmission, epigenetic effects and chimeral disruption. Plant Cell Tissue Org. Cult. 26:115-125.

Irvine JE, Benda GTA, Legendre BL and Machado Jr. GR (1984) The frequency of marker changes in sugarcane plants regenerated from callus culture. Plant Cell Tissue Org. Cult. 3:201-209.

Karp A (1995) Somaclonal variation as a tool for crop improvement. Euphytica 85:295-302.

Kovarik A. Koukalova B. Bezdek M and Opatrny Z (1997) Hypermethylation of tobacco heterochromatic loci in response to osmotic stress. Theor. Appl. Genet. 95:301-306.

Larkin P and Scowcroft WR (1981) Somaclonal variation - a novel source of variability from cell cultures for plant improvement. Theor. Appl. Genet. 60:197-214.

Lee TSG (1987) Micropropagation of sugarcane (Saccharum spp.) Plant Cell Tissue Org. Cult. 10:47-55.
Murashige T and Skoog F (1962) A revised medium for rapid growth and bioassays with tobacco tissue cultures. Physiologia Plantarum 15:473-497.

Murray MG and Thompson WF (1980) Rapid isolation of high molecular weight plant DNA. Nucleic Acids Res. 8:1134-1137.

Peros JP, Bonnel E, Roques D and Paulet F (1994) Effect of in vitro culture on rust resistance and yield in sugarcane. Field Crops Res. 37:113-119.

Peschke VM, Phillips RL and Gengenbach BG (1991) Genetic and molecular analysis of tissue-culture-derived Ac elements. Theor. Appl. Genet. 82:121-129.

Phillips RL, Kaeppler SM and Olhoft P (1994) Genetic instability of plant tissue cultures - breakdown of normal controls. Proc. Natl Acad. Sci. USA 91:5222-5226.

Phillips RL, Kaeppler SM and Peschke VM (1990) Do we understand somaclonal variation? In: Nijkamp, HJJ, Van Der Plas LHW and Van Aartrijk J (eds) Progress in Plant Cellular and Molecular Biology. International Congress of Plant Tissue and Cell Culture, Amsterdam, pp. 131-141.

Rani V, Parida A and Raina SN (1995) Random amplified polymorphic DNA (RAPD) markers for genetic analysis in micropropagated plants of Populus deltoides Marsh. Plant Cell Rep. 14:459-462.

Rogers SO and Bendich AJ (1985) Extraction of DNA from milligram amounts of fresh, herbarium and mummified plants tissues. Plant Mol. Biol. 5:69-76.

Rout GR, Das P, Goel S and Raina SN (1998) Determination of genetic stability of micropropagated plants of ginger using random amplified polymorphic DNA (RAPD) markers. Botan. Bull. Acad. Sin. 39:23-27.

Shoyama Y, Zhu XX, Nakai, R, Shiraishi S and Kohda H (1997) Micropropagation of Panax notoginseng by somatic embryogenesis and RAPD analysis of regenerated plantlets. Plant Cell Rep. 16:450-453.

Silvarolla MB (1992) Plant genomic alterations due to tissue culture. J. Brazil. Assoc. Adv. Sci. 44:329-335.

Silvarolla MB and Aguiar-Perecin MLR (1994) Evaluation of chromosome number stability in two sugarcane varieties. Rev. Bras. Genet. 17:237-242.

Smulders MJM, Rus-Kortekass W and Vosman B (1995) Tissue culture-induced DNA methylation polymorphisms in repetitive DNA of tomato calli and regenerated plants. Theor. Appl. Genet. 91:1257-1264.

Taylor PWJ, Geijskes JR, Ko H-L, Fraser TA, Henry RJ and Birch RG (1995) Sensitivity of random amplified polymorphic DNA analysis to detect genetic change in sugarcane during tissue culture. Theor. Appl. Genet. 90:1169-1173.

Todoroviska E, Trifonova A, Petrova M, Vitonova Z and Marinova E (1997) Agronomic performance and molecular assessment of tissue culture derived barley lines. Plant Breed. 166:511-517.

Vieira MLC, Fungaro MHP, Jubier M-F and Lejeune B (1997) Determination of taxonomic relationships among Brazilian taxa of Stylosanthes Sw., Leguminosae, using RAPD markers. Pesq. Agropec. Bras. 32:305-310.

Zucchi MI, Vieira MLC and Arizono H (1996) O uso de RAPD na análise da variação somaclonal de cana-de-açucar. Congresso Nacional da Sociedade dos Técnicos Açucareiros e Alcooleiros do Brasil, 6, Maceió, Anais, pp. 282-286. 